\title{
DETECTION OF AEROLYSIN (aerA) GENE IN AEROMONAS HYDROPHILA STRAINS ISOLATED FROM DISEASED CARP
}

Vladimir Radosavljević ${ }^{*}$, Miroslav Ćirković , Dragana Ljubojević́ ${ }^{2}$ Nikolina Novakov ${ }^{3}$, Đorđe Cvetojević ${ }^{1}$, Jadranka Zutić ${ }^{1}$, Vesna Milićević ${ }^{1}$

${ }^{1}$ Institute of Veterinary Medicine of Serbia, Belgrade, Serbia

${ }^{2}$ Scientific Veterinary Institute "Novi Sad", Novi Sad, Serbia

${ }^{3}$ Faculty of Agriculture, Novi Sad, Serbia

\section{Abstract}

Bacterial septicemia caused by motile aeromonads is common infection in the intensive fish production. Aeromonas (A.) hydrophila is often present in fish populations. Ubiquitous distribution of these bacteria in the aquatic environment, and the stress caused by intensive breeding are predisposing factors for the occurence of the disease. A. hydrophila is considered a major cause of septicaemia caused by motile aeromonads. Several A. hydrophila extracellular products (ECP) are considered as important factors in pathogenesis, primarily aerolysin (aerA), the extracellular lipase, cytolytic enterotoxin, hemolytic toxin and extracellular proteases. PCR detection of aerolysin $(\operatorname{aer} A)$ is considered a reliable method of identifying potentially pathogenic Aeromonas strains. In spring 2012, after a sudden increase in water temperature, disease occured in common carp population in one fish farm in Serbia. Five specimens of the one-year-old carp with clinical symptoms of motile aeromonas septicaemia were used for isolation of the bacteria. Identification of A. hydrophila was done on the basis of morphological, physiological, cultural and biochemical characteristics. PCR amplification of DNA from A. hydrophila isolates revealed presence of aerolysin (aerA) gene in all examined A. hydrophila isolates from carp with motile aeromonas septicaemia.

Key words: Aeromonas hydrophila, PCR, aerolysin, carp

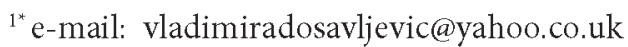




\title{
DOKAZIVANJE PRISUSTVA AEROLIZIN (aerA) GENA PATOGENIH SOJEVA AEROMONAS HYDROPHILA IZOLOVANIH IZ OBOLELIH ŠARANA
}

\author{
Vladimir Radosavljević, Miroslav Ćirković, Dragana Ljubojević, \\ Nikolina Novakov, Đorđe Cvetojević, Jadranka Žutić, Vesna Milićević
}

\section{Kratak sadržaj}

Bakterijske septikemije izazvane pokretnim predstavnicima roda Aeromonas spadaju u česte infekcije riba u intezivnom gajenju, ali zahvataju i populacije riba otvorenih voda. Široka rasprostranjenost ovih bakterija u vodenoj sredini, i stres uslovljen intenzivnim gajenjem predstavljaju predisponirajuće faktore za nastanak oboljenja. Aeromonas hydrophila je primarni ili sekundarni uzročnik bolesti vodenih i kopnenih životinja i ljudi, i njegova patogenost je povezana s faktorima virulencije. A. hydrophila se smatra glavnim uzročnikom septikemije izazvane pokretnim aeromonadama. Nekoliko ekstracelularnih proizvoda (ECP) bakterije A. hydrophila se smatraju značajnim faktorima u patogenezi, pre svega aerolizin (aerA), ekstracelularne lipaze, citolitički enterotoksin, hemolitički toksin i ekstracelularne proteaze. Detekcija aerA pomoću PCR se smatra pouzdanim načinom identifikacije potencijalno patogenih sojeva Aeromonas hydrophila. Kod šarana u prolećnom periodu, prilikom naglog povišenja temperature vode, utvrđena je septikemična forma oboljenja koja je podsećala na prolećnu viremiju šarana. Pet primeraka jednogodišnje mlađi šarana sa kliničkim simptomima bakterijske infekcije su korišćeni za izolaciju bakterija. Identifikacija $A$. hydrophila izvršena je na osnovu morfoloških, fizioloških, kulturelnih i biohemijskih karakteristika. Za identifikaciju gena virulencije odabrane su kolonije A. hydrophila izrasle u čistoj kulturi na Rimler-Shotts medijumu. PCR amplifikacijom DNK iz izolata $A$. hydrophila dobijeni su PCR produkti veličine $462 \mathrm{bp}$ kod svih ispitivanih uzoraka. U našem istraživanju, pomoću PCR je dokazano prisustvo aerolizin gena kod patogenih sojeva $A$. hydrophila izolovanih iz obolelih šarana.

Ključne reči: Aeromonas hydrophila, PCR, aerolizin, šaran

\section{INTRODUCTION}

Aeromonas hydrophila, a Gram-negative, motile rod that is a member of the family Aeromonadaceae (Joseph \& Carnahan 2000; Abbott et al. 2003), has 
been widely studied and is regarded as the most important bacterium causing "aeromonosis or haemorrhagic septicaemia or motile aeromonas septicaemia" in fish (Rhaman et al. 2001) and other aquatic animals (Hill et al. 2010; Pearson et al.2000). There have been a number of epidemiological studies indicating Aeromonas species as a cause of diarrheal disease in children, elderly people and immunocompromised patients (Figueras, 2005; von Gravaenitz, 2007).

The widespread of the bacteria in the aquatic environment and the stress caused by intensive breeding are predisposing factors for the disease. Stressful environmental factors, especially high water temperature, high levels of ammonia and nitrite, sudden changes in $\mathrm{pH}$, and low concentrations of oxygen increases the possibility of disease occurence (Jeremic et al. 2005).

Several extracellular products (ECP) of $A$. hydrophila are considered important virulence factors, primarily aerolysin, extracellular lipase, cytolytic enterotoxin, hemolytic toxin and extracellular protease (John et al., 1997, Shome et al., 2005). Detection of virulence genes by PCR is very useful for the identification of pathogenic isolates of aeromonads (Uzbas et al., 2000).

Detection of aerolysin (aerA) using PCR and RFLP is considered a reliable for identification of virulent strains of $A$. hydrophila (Kingombe et al., 1999). The aim of this study was to determine the presence of aerA gene in $A$. hydrophila strains isolated from carp with motile aeromonad septicaemia.

\section{MATERIAL AND METHODS}

Five samples of the one-year-old carp with clinical symptoms of bacterial infection were used for isolation. From each fish, samples were collected from the kidney, liver, spleen and gills. The samples were streaked on tryptic soy agar (TSA, HiMedia), Mueller-Hinton agar (HiMedia) containing 5\% defibrinated sheep blood erythrocytes (BA), selective Rimler-Shotts (RS) media (HiMedia), and incubated at $30^{\circ} \mathrm{C}$ for 24 to $48^{\mathrm{h}}$. Following incubation, one typical colony (entire circular, convex, white to greyish, semitranslucent, size 2 to $3 \mathrm{~mm}$, haemolytic) was selected from each plate with a pure culture and subcultivated in order to test the purity of isolates. The isolates were preliminary grouped according to colony morphology, haemolysis, and pigmentation before they were stored at $-80^{\circ} \mathrm{C}$ in $15 \%$ glycerol until further characterization. The type strain of Aeromonas hydrophila ATCC 7966 (American Type Culture Collection) was included in the phenotypic characterization.

Isolates were classified as Aeromonas hydrophila according to their reactions in the API 20E (Biomerieux) and following conventional tests, based on standard bacterial taxonomic procedures (Holt et al 1994; Austin and Austin, 2007). 
For identification of virulence genes, five colonies of $A$. hydrophila were selected and 24 hours old cultures were used for extraction of genomic DNA. DNA extraction was performed using commercial kit (QIAamp DNA Mini Kit, Qiagen) according to manufacturer's protocol. Detection of the aerolysin gene was performed using polymerase chain reaction (PCR) (Chu et al., 2005). Primers were used to detect 462bp aerolysin gene fragment (Aero1: 5'-CTCAGTCCGTGCGACCGACT-3' and Aero2: 5'-GATCTCCAGCCTCAGGCCTT-3'). Amplification was performed by 35 cycles of denaturation at $95^{\circ} \mathrm{C}$ for $1 \mathrm{~min}$, annealing at $56^{\circ} \mathrm{C}$ for $2 \mathrm{~min}$ and extension at $72^{\circ} \mathrm{C}$ for $2 \mathrm{~min}$. After amplification, PCR products were characterized by $1.5 \%$ agarose gel electrophoresis in Tris-borate-EDTA buffer.

\section{RESULTS}

On a carp pond, localized in the northeastern part of the Republic of Serbia, in the spring, during a sudden increase in water temperature, increased mortality of young carp occured. The main signs of the diseased fish were anorexia, exophthalmus, redding due to haemorrhage of the skin and swimming at the surface of the pond, near fresh water supply. In scaled fish, scale pockets become edematous, causing lepidorthosis (Figure 1). Internal organs were edematous with hemorrhage and erythema on liver and kidney. 
Figure 1. The pathological symptoms of the common carp suffering from motile aeromonad septicemia.

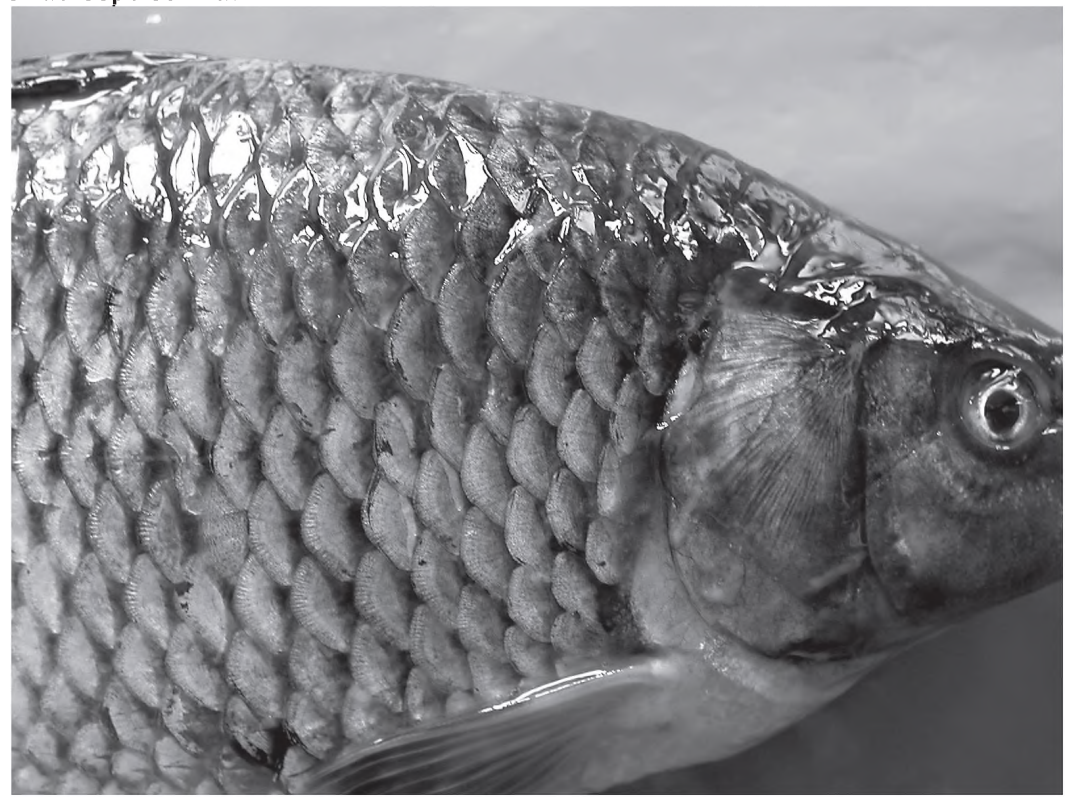

Pure cultures of Aeromonas hydrophila were obtained from all samples (Figure 2). Figure 2. Growth of Aeromonas hydrophila on Rimler-Shotts medium.

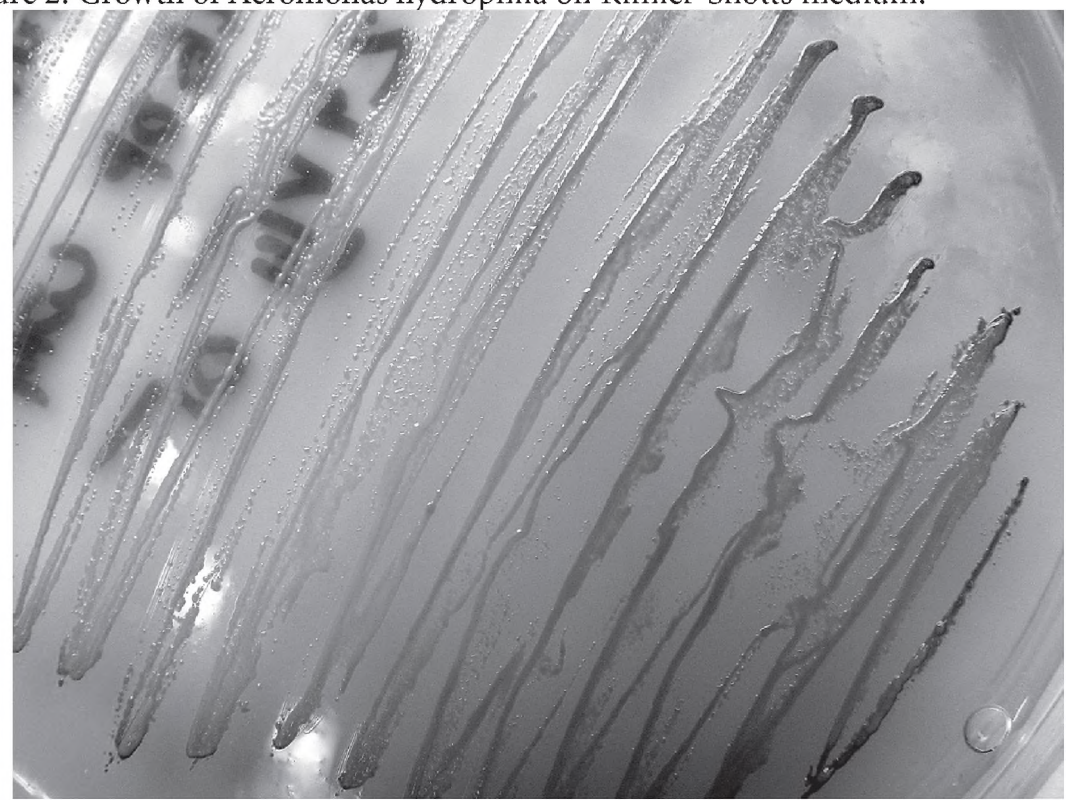


A PCR amplification revealed that all $A$. hydrophila isolates were PCR positive for the aerA gene.

Figure 3: PCR amplification of A.hydrophila isolates for the 426-bp aerA gene.

Lane M, 100-bp molecular weight marker; lane 1-5, 426-bp aerA amplified from the genomic DNA, lane 6-negative control, lane 7-positive control.

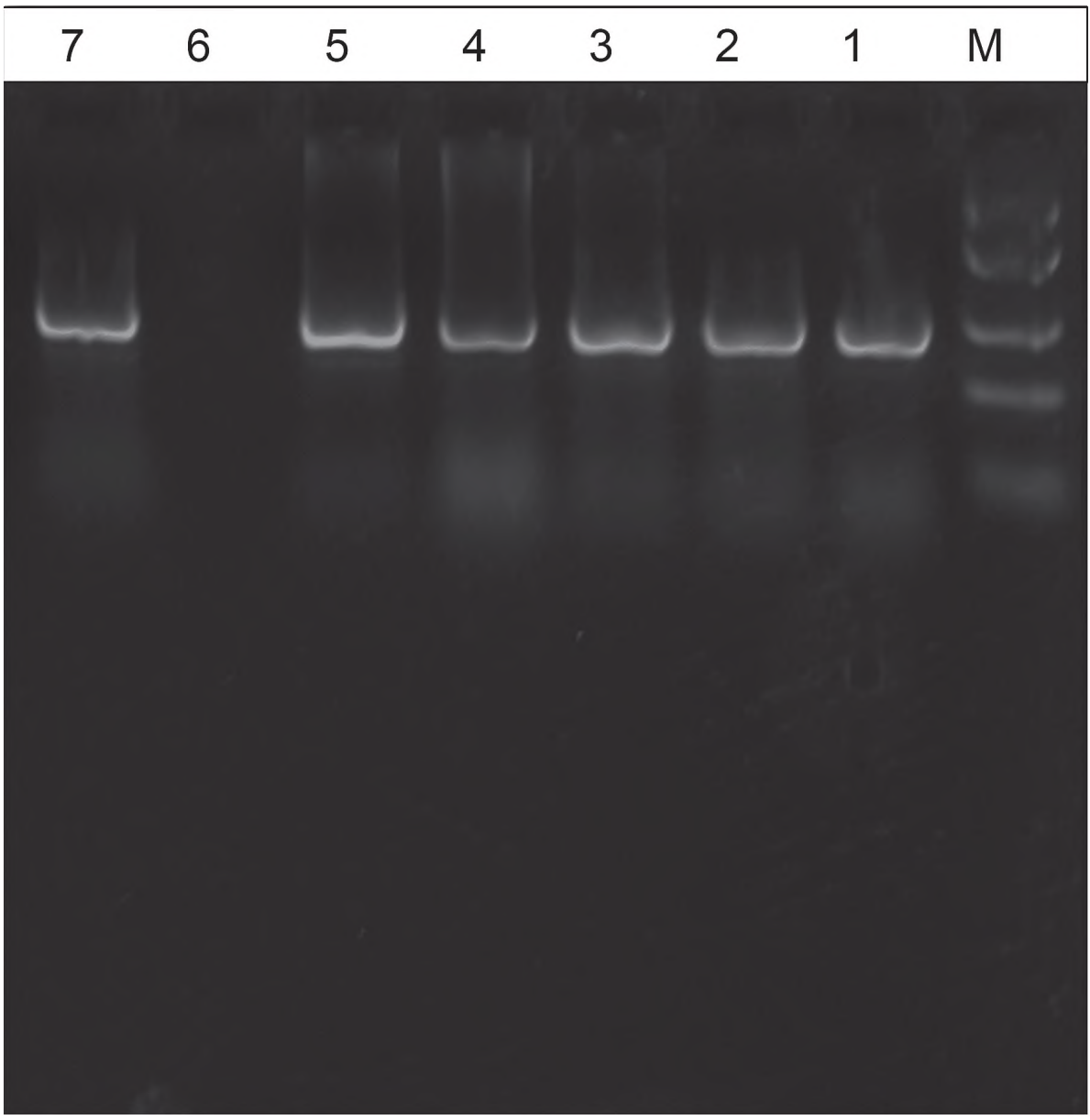

\section{DISCUSSION}

Motile aeromonads cause different pathologic conditions that include acute, chronic and latent infection. Severity depends on a number of factors including bacterial virulence, type and level of stress, resistance and physiological state of the host. In the acute phase, this condition is characterized by rapid fatal septicemia with little macroscopic evidence of disease. When present, the 
most important symptoms are exophthalmos, skin redness and fluid collection in the scale pockets (Faktorovich, 1969).

There is evidence that the motile Aeromonas complex involves secondary and opportunistic pathogens, but ability of $A$. hydrophila to cause disease and death of fish should not be overlooked because occasionally highly virulent strains emerge. Regardless of whether or not the organism serves as a primary or secondary invader of stressed fish, it is often the final insult that leads to death (Plumb and Hanson 2011).

In attempt to explain the pathogenesis of infection caused by $A$. hydrophila several virulence factors were investigated. Toxins with haemolytic, cytotoxic and enterotoxic activities have been described in many Aeromonas spp. (Chopra et al., 1990).

Although rare, A. hydrophila may cause high mortality among cultured fish without presence of severe external (stressful) influences. This inconsistency may result from the presence of $\mathrm{A}$. hydrophila strains that possess specific virulent or pathogenic characteristics (Plumb and Hanson 2011).

In our study, PCR was performed to detect aerolysin (aer $A)$ gene as a genetic marker for the determination of virulence. Role of aerolysin (aerA) gene in the pathogenicity of Aeromonas genus was previously demonstrated (Kozaki et al., 1989, Shaw, 2003). In present study, PCR amplification of A.hydrophila isolates for the 426-bp aerA gene, in samples from diseased fish, showed the presence aerolysin gene, which is an essential A. hydrophila virulence gene. Similar results were obtained in previous studies with $A$. jandaei (Chacón, 2003). It is well known that the screening of specific cytotoxin and hemolysin genes is the most effective way of detecting and characterizing Aeromonas virulence factors (Yousr et al., 2007).

\section{CONCLUSIONS}

Despite disagreement among scientists regarding significance of $A$. hydrophila infection, the frequency of its appearance in aquaculture environment, together with a high potential for stress, shows that this problem sholud not be ignored, because it is often what kills the fish. PCR test for the detection of aerolysin gene proved to be a useful tool for the detection of virulent strains of Aeromonas hydrophila.

\section{ACKNOWLEDGEMENT}

This study was financially supported by a grant from the Ministry of Education and Science of the Republic of Serbia, under the project TR31075, TR-31011. 


\section{LITERATURE}

1. Abbott S.L., Cheung W.K.W. \& Janda J.M.: The genus Aeromonas: biochemical characteristics, atypical reactions, and phenotypic identification schemes. Journal of Clinical Microbiology 41, 2348-2357, 2003.

2. Austin, B. and Austin, D.A.: Bacterial Fish Pathogens: Diseases of Farmed and Wild Fish, 4th edn. Chichester, UK: Springer-Praxis, 2007.

3. Chacón, M.R., M.J. Figueras, G. Castro-Escarpulli, L. Soler, J. Guarro. Distribution of virulence genes in clinical and environmental isolates of Aeromonas spp. Antonie van Leeuwenhoek, 84 (4), 269-78, 2003.

4. Chopra, A.K., C.W. Houston and Kurosky A.: Genetic variation in related cytolytic toxins produced by different species of Aeromonas. FEMS. Microbiol. Lett., 78, 231-7, 1990.

5. Chu, W.H and Lu, C.P.. Multiplex PCR assay for the detection of pathogenic Aeromonas hydrophila. Journal of Fish Diseases, 28, 437-41, 2005.

6. Faktorovich, K. A.: Histological changes in the liver, kidneys, skin and brain of fish sick with red rot. Infectious diseases of fish and their control. Division of Fisheries Research Bureau of Sport Fisheries and Wildlife. Washington, D. C, 83-101, 1969.

7. Hill, W. A., Newman, S. J., Craig, L., Carter, C., Czarra, J. \& Brown, P.: Diagnosis of Aeromonas hydrophila, Mycobacterium species, and $\mathrm{Ba}$ trachochytrium dendrobatidis in an African Clawed Frog (Xenopus laevis). J Am. Assoc. Lab. Anim. Sci. 49, 2, 215-220, 2010.

8. Holt, J.G., Krieg, N.R., Sneathm, P.H.A., Staley, J.T. and Williams, S.T.: Bergey's Manual of Determinative Bacteriology, 9th edn. Baltimore, MD: Williams and Williams, 1994.

9. Figueras M.J.: Clinical revelance of Aeromonas spp. Rev. Clin. Microbiol. 16, 145-153, 2005.

10. Jeremić Svetlana, Radosavljević V., Jakić-Dimić, Dobrila.: Current bacterial diseases of freshwater fish. Biotechniology and Animal Husbandry.; 21, 3-4, 141-51, 2005.

11. John M.P., Stephen P.K. \& Radomin S. Secreted enzymes of Aeromonas. FEMS Microbiology Letters. 15, 1-10, 1997.

12. Joseph S.W. \& Carnahan A.M. Update on the genus Aeromonas. American Society for Microbiology News 66, 218- 223, 2000.

13. Kingombe, C.I., G. Huys, M. Tonolla, M.J. Albert, J. Swings, R. Peduzzi and T. Jemmi. PCR detection, characterization and distribution of virulence genes in Aeromonas spp. Appl. Environ. Microbiol., 65, 5293-302, 1999. 
14. Kozaki, S., A. Tsutomu, K. Yoichi and G. Sakaguchi.: Characterization of Aeromonas sobria hemolysin by use of monoclonal antibodies against Aeromonas hydrophila hemolysins. J. Clin. Microbiol., 27, 1782-86, 1989.

15. Pearson MD, Hirono I, Aoki T, Miranda R, Inglis V.: Virulence properties of motile aeromonads isolated from farmed frogs Rana tigerina and R. rugulosa. Dis Aquat Organ., 40, 3, 185-93, 2000.

16. Plumb JA, Hanson LA : Motile Aeromonas septicemia (MAS). In: Plumb JA, Hanson LA (Eds): Health maintenance and principal microbial diseases of cultured fshes, 3rd edition. Blackwell Publishing pp. 293-300, 2011.

17. Rhaman M.H., Suzuki S. \& Kawai K.: The effect of temperature on Aeromonas hydrophila infection in goldfish, Carassius auratus. Journal of Applied Ichthyology 17, 282-285, 2001.

18. Shaw, D., H.J. Hodder,. Lipolysaccharides of the motile aeromonads; core oligosaccharides analysis as an aid to taxonomic classification. Can. J. Microbiol., 864-68, 2003.

19. Shome, R. , B., R. Shome., Y. Mazumder., A. Das., A. Kumar., H. Rahman, Bujarbaruah K. M. Abdominal dropsy disease in major carps of Meghalaya: Isolation and characterization of Aeromonas hydrophila. Current Science, 88, 12, 2005

20. Uzbas Z.Y., Lehner A. \& Wagner M.: Development of a multiplex and semi-nested PCR assay for detection of Yersinia enterocolitica and Aeromonas hydrophila in raw milk. Food Microbiology, 17, 197 - 203, 2000.

21. Von Gravenitz A.: The role of Aeromonas in diarrhea: a review. Infection 35, 59-64, 2007.

22. Yousr, A.H., Napis, S., Rusul, G.R.A. and R. Son.: Detection of Aerolysin and Hemolysin genes in Aeromonas spp. isolated from environmental and shellfish sources by polymerase chain reaction. ASEAN Food Journal, 14, 2, 115-22, 2007.

Received / Primljeno: 11.10.2013. Accepted / Odobreno: 08.12.2013. 